\title{
Enhancement of Tomato Fruit Lycopene by Potassium Is Cultivar Dependent
}

\author{
Henry Taber ${ }^{2}$ \\ Department of Horticulture, Iowa State University, Ames, IA 50011
}

Penelope Perkins-Veazie

USDA-Agricultural Research Service, Lane, OK 74555

\author{
Shanshan Li' and Wendy White \\ Department of Food Science and Human Nutrition, Iowa State University, \\ Ames, IA 50011
}

\author{
Steven Rodermel and Yang Xu \\ Department of Genetics, Development, and Cell Biology, Iowa State \\ University, Ames, IA 50011
}

Additional index words. carotenoids, maturity, nutrient, crimson gene

\begin{abstract}
The purpose of this experiment was to determine the response of tomato (Solanum lycopersicum $\mathbf{L}$.) cultivars with fruit of average and high lycopene to increased $\mathrm{K}$ fertilization. The field experiment was designed as a factorial, split-plot, randomized complete block with four replications. The main plot consisted of $\mathrm{K}$ rates ranging from 0 to $372 \mathrm{~kg} \cdot \mathrm{ha}^{-1} \mathrm{~K}$ as $\mathrm{KCl}$, and the subplot was cultivar ('Mountain Spring' or the highlycopene Florida hybrid, 'Fla. 8153'). The soil type was a well-drained, central Iowa loam with a soil test level considered low. The soil $\mathrm{K}$ application effect on total marketable fruit

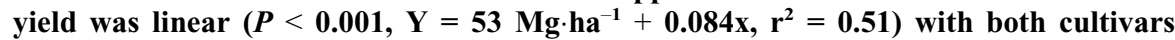
responding similarly. Fruit $K$ analysis indicated a linear response to fertilization across four harvest dates, from 1236 to $1991 \mathrm{mg} \cdot \mathrm{kg}^{-1}$, fresh weight basis. Harvest date had no effect on fruit lycopene concentration, but there was a significant $(P=0.006)$ interaction of $\mathrm{K}$ fertilization rate and cultivar. Overall, 'Fla. 8153' contained $9.5 \mathrm{mg} \cdot \mathrm{kg}^{-1} \mathrm{more}$ lycopene in fruit tissue than 'Mountain Spring'. 'Mountain Spring' lycopene concentration was not enhanced by higher $K$ fertilization $\left(44.2 \mathrm{mg} \cdot \mathrm{kg}^{-1}\right)$. 'Fla. 8153 ' lycopene concentration increased $21.7 \%$ at the highest $K$ rate compared with lower rates $(62.9 \mathrm{vs}$. $51.7 \mathrm{mg} \cdot \mathrm{kg}^{-1}$, respectively). A controlled greenhouse study in the fall of 2005 with the same cultivars indicated similar results. Fruit $K$ concentration for 'Fla. 8153' was significantly $(P<0.01)$ correlated to the fruit carotenoids, phytoene and phytofluene, indicating a possible role for $K$ in one of the enzymes that synthesize phytoene. In the field and greenhouse studies, increasing fruit $K$ concentration in the high-lycopene 'Fla. 8153' depressed fruit $\beta$-carotene by $53 \%$. These results indicate that $K$ fertilization can affect carotenoid biosynthesis, and the response of tomato to a high $K$ rate is genotype dependent.
\end{abstract}

Functional foods contain bioactive ingredients known as phytochemicals or nutraceuticals that may increase health and fitness. Such a phytochemical is the carotenoid lycopene found in tomato fruit, and it is associated with the inhibition of heart disease (Rissanen et al., 2003) and certain cancers,

Received for publication 11 June 2007. Accepted for publication 28 Aug. 2007.

This work was funded, in part, by a USDA award to the ISU Center for Designing Foods to Improve Nutrition (grant no. 2004-34115-14842) and by the Foundation for Agronomic Research.

We thank John Scott, University of Florida, for supplying the Fla. 8153 seed for the trials.

${ }^{1}$ Current address: Department of Pharmaceutics, Rutgers University, 160 Frelinghuysen Road, Piscataway, NJ 08854.

${ }^{2}$ To whom reprint requests should be addressed; e-mail taber@iastate.edu most notably, prostate cancer (Ansari and Gupta, 2003; Giovannucci, 2002). The mode of action is uncertain, but carotenoids are believed to reduce cancer risk by effectively trapping oxygen and free oxygen radical intermediates (Palozza and Krinsky, 1992). Lycopene and $\beta$-carotene account for $90 \%$ of the total carotenoids in raw tomato fruit, with lycopene five to six times the concentration of $\beta$-carotene (Ong and Tee, 1992). Consumer demand for lycopene-rich foods is growing based on recent reports that suggest an important role for lycopene in human health. This increased demand, in turn, has prompted research to identify means to increase lycopene production in tomato fruit (Minorsky, 2002).

Manipulation of germplasm by breeding techniques is the most common means for increasing the lycopene content of fruit (Lester and Crosby, 2002). Several genes are available to increase lycopene, including the crimson $\left(\operatorname{og}^{\wedge} \mathrm{c}\right)$ gene (Stommel, 2007). Use of the crimson gene can increase the amount of lycopene in tomato fruit by $50 \%$ (Thompson et al., 1967), but this gene has undesirable effects that must be eliminated through additional crosses. The production environment (light, temperature, and fertility) can also affect lycopene production. Sunburn or high ultraviolet light can trigger $\beta$-carotene production at the expense of lycopene in tomato fruit as can air temperatures in excess of $30{ }^{\circ} \mathrm{C}$ (Robertson et al., 1995; RodriquezAmaya, 2001).

Under deficient soil $\mathrm{K}$ conditions, the tomato fruit will be small, drop from the plant prematurely, and lack red color (poor lycopene development), and can lead to blotchy ripening (Widders and Lorenz, 1979). Blotchy ripening is the result of uneven coloring, with typical symptoms of yellow shoulders and white, internal tissue. The condition is a common but unpredictable problem, and it is often severe enough to render the fruit unsuitable for market.

Fruit red color and ripening disorders are correlated with fruit $\mathrm{K}$ content (PerkinsVeazie and Roberts, 2003; Trudel and Ozbun, 1971). Generally, K fertilization for maximum yield is also adequate for high color development in standard tomato cultivars (Besford and Maw, 1975; Wilcox, 1964). Recently, K fertilizer additions above that needed for high yields have been shown to reduce fruit color disorders, but there was no direct measurement of fruit lycopene content (Hartz et al., 1999). Evidence of fertilization for increased nutritional quality comes from work with vitamin C. Anac and Colakoglu (1995) found that maximum tomato yield was achieved at $110 \mathrm{~kg} \cdot \mathrm{ha}^{-1} \mathrm{~K}$, but another $55 \mathrm{~kg} \cdot \mathrm{ha}^{-1} \mathrm{~K}$ was needed for maximum fruit vitamin $\mathrm{C}$ content.

The ripening of tomato fruit, from green to full red, involves the accumulation of lycopene and carotenoids and the disappearance of chlorophyll. In fruit, colorless precursor carotenoids, phytoene and phytofluene, lead to lycopene synthesis at the breaker stage (fruit blossom green end breaks with red streaks, $<10 \%$ color change) (Barr et al., 2003; Rodriquez-Amaya, 2001; Trudel and Ozbun, 1971). The outer tomato wall (pericarp) contains the highest concentration of lycopene compared with the internal fluid (locular cavity), and the stage of fruit ripeness is critical for its quantification of lycopene (Rodriquez-Amaya, 2001). Fraser et al. (1994) found an 11-fold increase in fruit lycopene content from the initial breaker stage to $14 \mathrm{~d}$ past breaker. Potassium has many effects in the plant cell, and is thought to generally affect enzymes through its necessity as a cofactor for protein synthesis. Protein synthesis requires a high cellular $\mathrm{K}$ concentration, $>120 \mathrm{~mm}$, for the transcription process and for the binding of tRNA to ribosomes (Wyn Jones and Pollard, 1983). Potassium deficiency is assumed to lower enzyme activity, but the effect of excess $\mathrm{K}$ on enzyme activity, or the specific role of $\mathrm{K}$ in 
lycopene synthesis, is not known. It is essential for the pyruvic kinase and acetic thiokinase enzymes that are directly involved in lycopene synthesis. Potassium may also affect lycopene synthesis through enhanced enzymatic activity in carbohydrate metabolism, providing the necessary substrates for terpenoid synthesis (Fanasca et al., 2006). A basic, inexpensive approach to maximize lycopene production can be through an effective crop management practice, such as adequate $\mathrm{K}$ nutrition, alone or in conjunction with genetic modification of the tomato plant.

The purpose of our study was to determine the extent to which $\mathrm{K}$ fertilization can enhance tomato fruit lycopene content beyond that attained when the amount of soil-added $\mathrm{K}$ is sufficient to maximize fruit yield, and to elucidate $\mathrm{K}$ effects on compounds produced in the carotenoid pathway.

\section{Materials and Methods}

\section{Field studies}

Five-week-old tomato greenhouse transplants, raised in 72-cell packs in a standard 1020 flat, were transplanted to field plots at the Horticulture Station, Ames, Iowa, on 15 May 2004. The culture system included black polyethylene mulch with a single-line source trickle irrigation system (16-mm tubing, 30-cm emitter spacing, $2 \mathrm{~L} / \mathrm{h}$; Toro MicroIrrigation Co., El Cajon, CA). The previous crop rotational scheme was soybeans (Glycine $\max$ ) and cereal rye (Secale cereale). The soil type was a well-drained loam (prairie developed on glacial till, fine-loamy, mixed, mesic Typic Hapudoll) with 2.4\% organic matter, 13.1 cation exchange capacity, and a water $\mathrm{pH}$ of 6.9 as measured in the surface $20 \mathrm{~cm}$. Irrigation was applied uniformly to all plots from a collection pond to maintain 23-cm depth tensiometer (Irrometer Co., Riverside, CA) readings at 30 to $35 \mathrm{kPa}$.

Soil test levels of $\mathrm{P}$ and $\mathrm{K}$ as determined by Mehlich No. 3 methodology (Brown, 1998) indicated optimum soil $\mathrm{P}\left(31 \mathrm{mg} \cdot \mathrm{kg}^{-1}\right)$ and very low exchangeable $\mathrm{K}$ levels (89 $\left.\mathrm{mg} \cdot \mathrm{kg}^{-1}\right)$. The experimental design was a factorial, split-plot, randomized completeblock with four replications. The whole plot was $\mathrm{K}$ rate $\left(0,23,46,93,186\right.$, and $372 \mathrm{~kg} \cdot \mathrm{ha}^{-1}$ as $0 \mathrm{~N}-0 \mathrm{P}-51.5 \mathrm{~K}$ in the form of potassium chloride) and the subplot was cultivar, either 'Mountain Spring' (standard commercial fresh-market cultivar, North Carolina Agricultural Expermiental Station) or 'Fla. 8153' [a recent high-lycopene fresh market release containing the $\operatorname{og}^{\wedge} \mathrm{c}$ gene but not the high pigment (hp) gene, Florida Agricultural Experimental Station]. Both cultivars have a determinate growth habitat. One-half of the $\mathrm{K}$ fertilizer was broadcast uniformly over the plot area and plowed down (moldboard) on 27 Apr. The remaining one-half, along with $84 \mathrm{~kg} \cdot \mathrm{ha}^{-1} \mathrm{P}, 52 \mathrm{~kg} \cdot \mathrm{ha}^{-1} \mathrm{~N}$, and the herbicide trifluralin (Treflan; Dow AgroSciences, Indianapolis) was incorporated (rotovated to a $20-\mathrm{cm}$ depth) just before laying the $1.2-\mathrm{m}$ wide polyethylene film on $1.8-\mathrm{m}$ row centers. The mulch film was laid flat without a bed shaper. No fertilizer was applied through the drip system. Each $\mathrm{K}$ level main plot was four rows wide and $7.6 \mathrm{~m}$ long, oriented in an eastwest direction. The cultivar treatments consisted of a single-row with plant in-row spacing of $38 \mathrm{~cm}$. Plants were staked, pruned once to the first cluster, and tied according to the Florida stake and weave system (Konsler and Gardner, 1990). No insecticides were used, as field scouting indicated no insect pressure. Chlorothalonil (Bravo Ultrex; Syngenta, Greensboro, NC) and copper hydroxide (Kocide 2000; Dupont Crop Protection, Newark, DE) were used to control Septoria leaf spot. No other diseases were observed.

Fruit harvest began on 2 Aug. when 10\% of the fruit were at the breaker stage. All fruit showing color were harvested once per week until 20 Sept., which was a total of 8 weeks. Yield data included overall fruit size and weight of marketable and cull fruit. The marketable category was graded into four sizes: extra large $(>7.3 \mathrm{~cm}$ diameter $)$, large $(7.3-6.4 \mathrm{~cm})$, medium $(6.4-5.7 \mathrm{~cm})$, and small $(<5.7 \mathrm{~cm})$. Culls were fruit $<4 \mathrm{~cm}$, and those with rots, radial and concentric cracks, or with ripening disorders over more than $5 \%$ of the fruit surface.

Leaf sampling and analysis. Leaf samples were taken 5 weeks after transplanting, on 25 June, when the first and second flower clusters were actively flowering. The ten most recently matured whole leaves were collected from each treatment plot and dried in a forced air oven for $72 \mathrm{~h}$ at $67{ }^{\circ} \mathrm{C}$ and were then ground using a Wiley Mill to pass through a $1-\mathrm{mm}$ mesh screen. Leaf total $\mathrm{K}$ was determined by dry ashing, taking up the ash in $1 \mathrm{~N}$ aqua regia, and measuring $\mathrm{K}$ in the solution by inductively coupled plasma (ICP) techniques (Soltanpour et al., 1996).

Fruit sampling and analysis. At each harvest date, beginning with 9 Aug., two breaker-stage fruit on each plot were tagged and harvested $7 \mathrm{~d}$ later to minimize differences in lycopene accumulation due to maturity (Fraser et al., 1994; Thompson et al., 2000). The exception was 16 Aug. when four fruit were harvested for analysis. On harvest day, fruit were transported to the laboratory and washed with distilled water, air dried, and a $1.5-\mathrm{cm}$ equatorial slice was removed, weighed, and frozen at $-80{ }^{\circ} \mathrm{C}$ for future lycopene analysis. The remaining fruit halves were weighed, homogenized in a Waring blender for 1 min with distilled water $(1: 1$, $\mathrm{w} / \mathrm{v}$ ), centrifuged, and a representative aliquot was removed for $\mathrm{K}$ analysis by ICP techniques.

\section{Greenhouse studies}

Three commercial determinate tomato cultivars, 'Mountain Spring', 'Florida 91', and 'Fla. 8153', were grown from seed in soilless media (peat:perlite) to the third leaf stage of growth and were then transferred to 20-cm-diameter plastic pots containing silica sand. The experiment was conducted from Sept. to Dec. 2005 in a greenhouse $\left(22^{\circ} \mathrm{C} \pm\right.$ $5{ }^{\circ} \mathrm{C}$ day and night temperature) at Iowa State University (Ames). Natural irradiance was supplemented by $400-\mathrm{W}$ high-pressure sodium lamps that provided $70 \mu \mathrm{mol} \cdot \mathrm{s}^{-1} \cdot \mathrm{m}^{-2}$ of photosynthetically active radiation from 0600 to 2100 HR. Hoagland's No. 1 solution (Hoagland and Arnon, 1950) with $1 \mathrm{mg} \cdot \mathrm{L}^{-1}$ $\mathrm{Fe}$ as Fe-EDTA and $\mathrm{pH}$ adjusted to 6.0 with $5 \mathrm{~N} \mathrm{NaOH}$ was applied daily at a rate of $500 \mathrm{~mL}$ to each pot, except for the fifth day, when tap water was substituted. Fertigation increased to $750 \mathrm{~mL}$ daily after the second flower cluster developed. Four $\mathrm{K}$ fertigation levels $\left(0,2.5,5.0\right.$, and $10.0 \mathrm{~mm} \cdot \mathrm{L}^{-1}$; Table 1$)$ were initiated when the fruit on the first cluster were $\approx 5 \mathrm{~mm}$ in diameter. The three cultivars and four $\mathrm{K}$ levels were arranged in a factorial, randomized complete block design with four replications. The $\mathrm{K}$ treatments were applied at the rate of $1000 \mathrm{~mL}$ per pot daily, except for the fifth day, when tap water was substituted. Only two flower clusters were allowed to develop per plant by removing the apical shoot one leaf above the second flower cluster. Fruit number was held constant at four to five per flower cluster by pinching off the distal fruits. As the plants became larger, additional tap water was applied to avoid drought stress. All fruits were tagged when they reached breaker stage and were harvested $7 \mathrm{~d}$ later. The procedure of washing, sectioning, and storage at $-80^{\circ} \mathrm{C}$ was similar to the field samples. Fruit slices were analyzed for carotenoids by high-pressure liquid chromatography (HPLC) procedures in the ISU laboratory.

\section{Fruit carotenoid analysis}

Lycopene by colorimetric. Field fruit slice samples were transported to USDA-ARS (Lane, OK) and analyzed by colorimetric/ spectrophotometric techniques. One half of the equatorial slice was ground with an equal weight of water in a blender and then with a homogenizer (Polytron, shearing blade). Purees were poured into cuvettes and was absorbance measured at 560 and $750 \mathrm{~nm}$ using a colorimeter (Hunter Associates Laboratories, Reston, VA), xenon flash. Total lycopene content (milligrams per kilogram)

Table 1. Composition of nutrient solutions that provided $\mathrm{K}$ to greenhouse-grown tomatoes, Fall 2005.

\begin{tabular}{lcccc}
\hline & \multicolumn{4}{c}{$\mathrm{K}$ rate $\left(\mathrm{mM} \cdot \mathrm{L}^{-1}\right)$} \\
\cline { 2 - 5 } & 0 & 2.5 & 5 & 10 \\
\cline { 2 - 6 } Nutrient $^{\mathrm{z}}$ & $\mathrm{ml} \cdot \mathrm{L}^{-1}$ & of nutrient solution \\
\hline $0.05 \mathrm{M} \mathrm{Ca}\left(\mathrm{H}_{2} \mathrm{PO}_{4}\right)_{2}$ & 10 & 10 & 10 & 10 \\
$1 \mathrm{M} \mathrm{Ca}\left(\mathrm{NO}_{3}\right)_{2}$ & 5 & 5 & 5 & 5 \\
$1 \mathrm{M} \mathrm{NH}_{4} \mathrm{NO}_{3}$ & 2.5 & 1.25 & - & - \\
$2 \mathrm{M} \mathrm{KNO}_{3}$ & - & 1.25 & 2.5 & 2.5 \\
$0.5 \mathrm{M} \mathrm{K}_{2} \mathrm{SO}_{4}$ & - & - & - & 5 \\
$1 \mathrm{M} \mathrm{MgSO}_{4} \cdot 7 \mathrm{H}_{2} \mathrm{O}$ & 2 & 2 & 2 & 2 \\
\hline
\end{tabular}

${ }^{\mathrm{z}}$ All solutions contained the micronutrients, in milligram per liter: $\mathrm{B}=0.5 ; \mathrm{Mn}=0.5 ; \mathrm{Cu}=0.02$; $\mathrm{Zn}=0.05 ; \mathrm{Mo}=0.01 ;$ and $\mathrm{Fe}=1.0$ supplied as Fe-EDTA. Solution pH adjusted to 6.0 with $5 \mathrm{M}$ $\mathrm{NaOH}$. All solutions are balanced for cations and anions. The EC ranged from 2.1 to $2.4 \mathrm{dS} \cdot \mathrm{m}^{-1}$. The tap water contained, as milligrams per, $\mathrm{Ca}=152$; $\mathrm{Mg}=11 ; \mathrm{K}=2 ; \mathrm{Na}=22 ; \mathrm{Fe}=0.26$; other micronutrients were $<0.02$. The alkalinity was 0.55 meq. $\mathrm{L}^{-1}$ and the $\mathrm{pH}$ was 9.2. 
was determined from a standard curve developed for tomatoes, using the formula [Abs560-Abs750]*39.9. Randomly tested purees were sampled by spectrophotometer to verify colorimeter results using a reduced volume solvent extraction (Fish et al., 2002). In this system, $10 \mathrm{~mL}$ of hexane, $10 \mathrm{~mL}$ of ethanol, and $5 \mathrm{~mL}$ of acetone were added to $0.5 \mathrm{~g}$ of puree, shaken for $15 \mathrm{~min}$ using an orbital shaker, $5 \mathrm{~mL}$ of water was added, shaken for an additional $5 \mathrm{~min}$, and the hexane layer was measured at $503 \mathrm{~nm}$ on a spectrophotometer (UV160A; Shimadzu, Tokyo). Total lycopene content was determined using the extinction coefficient of 172,000 L·mol-cm (Zechmeister and Polgar, 1943).

Lycopene, phytoene, and phytofluene by $H P L C$. The extraction protocol was a modification of the method of Davis et al. (2003). The solvents used were HPLC grade. Field and greenhouse fruit slices were homogenized in a food processor (Handy Chopper Plus HC3000; Black \& Decker Corp., Towson, MD). A 0.6-g aliquot of tomato puree was placed into a $40-\mathrm{mL}$ screw-capped tube with a microstir bar. With constant stirring, $5 \mathrm{~mL}$ of acetone containing $0.1 \mathrm{~g}$ of butylated hydroxytoluene $\mathrm{L}^{-1}, 5 \mathrm{~mL}$ of ethanol containing $\beta$-apo- $8^{\prime}$-carotenal as the internal standard, and $10 \mathrm{~mL}$ of hexane were added to the sample. The tube was shaken on ice for $15 \mathrm{~min}$ at $180 \mathrm{rpm}$. Three milliliters of water was then added and the tube was again shaken for $5 \mathrm{~min}$. After standing at room temperature for $5 \mathrm{~min}$, the upper hexane layer was removed and dried in a vacuum evaporator (SPD131DDA; Thermo Electron Corporation, Milford, MA) with universal vacuum system (UVS800-115DDA; Thermo Electron Corporation). The resulting extract was reconstituted in $6 \mathrm{~mL}$ of methyl-tertbutyl ether (MTBE):methanol (1:1 by volume). A $25-\mu \mathrm{L}$ aliquot was injected into the HPLC system. The HPLC system's components included a 717 Plus autosampler with temperature control set at $5{ }^{\circ} \mathrm{C}$, two solventdelivery systems, and a 2996 photodiode array detector (all Waters Corporation, Milford, MA). The carotenoids were separated on a $5-\mu \mathrm{m} \mathrm{C}_{30}$ Carotenoid Column $(4.6 \times$ $250 \mathrm{~mm}$; Waters Corporation) and were eluted by using $100 \%$ methanol containing $1 \mathrm{~g} \cdot \mathrm{L}^{-1}$ ammonium acetate (solvent A) and 100\% MTBE (solvent B). The following gradient was used: 0 to $10 \mathrm{~min}, 100 \%$ solvent $\mathrm{A}$; 10 min to $45 \mathrm{~min}$, linear gradient to $100 \%$ solvent $\mathrm{B}$. The flow rate was $1.0 \mathrm{~mL} \cdot \mathrm{min}^{-1}$.

The lycopene, phytoene, and phytofluene peaks were integrated at 453, 286, and $348 \mathrm{~nm}$, respectively. Internal standard calibration curves were produced using commercially available $\beta$-apo- 8 '-carotenal and $\beta$-carotene (Fluka, Milwaukee, WI), and lycopene (Carotenature, Basel, Switzerland). The phytoene and phytofluene peak areas were normalized according to each carotenoid's specific molar absorption coefficient (Bartley et al., 1999). These two carotenoids were then quantified using the $\beta$-carotene calibration curve.

\section{Statistical analysis}

All field and greenhouse data were subjected to multiway analysis of variance (ANOVA) procedures to evaluate each main factor and their interactions. Sums of squares for $\mathrm{K}$ rate main effects were partitioned into single df for linear and quadratic orthogonal contrasts. When interactions were observed the standard error of difference (SED), as calculated from SAS/STAT MIXED procedure,

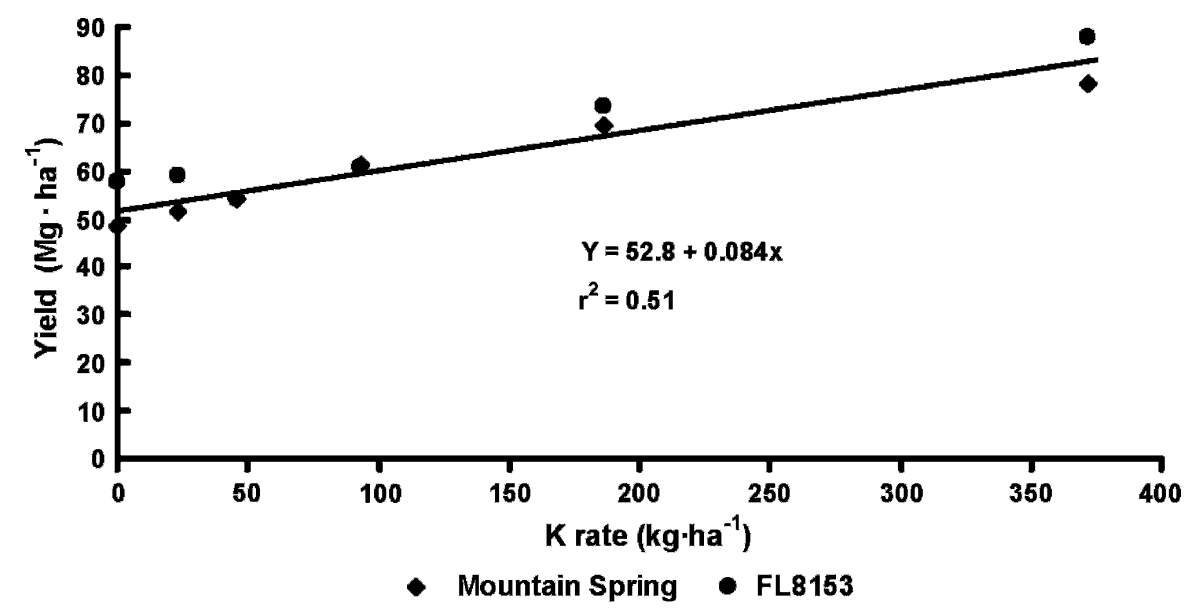

Fig. 1. Fertilizer $\mathrm{K}$ effect on total accumulative marketable tomato fruit yield. Linear regression best describes the marketable relationship. There was no effect of cultivar or $\mathrm{K}$ rate on cull yield.
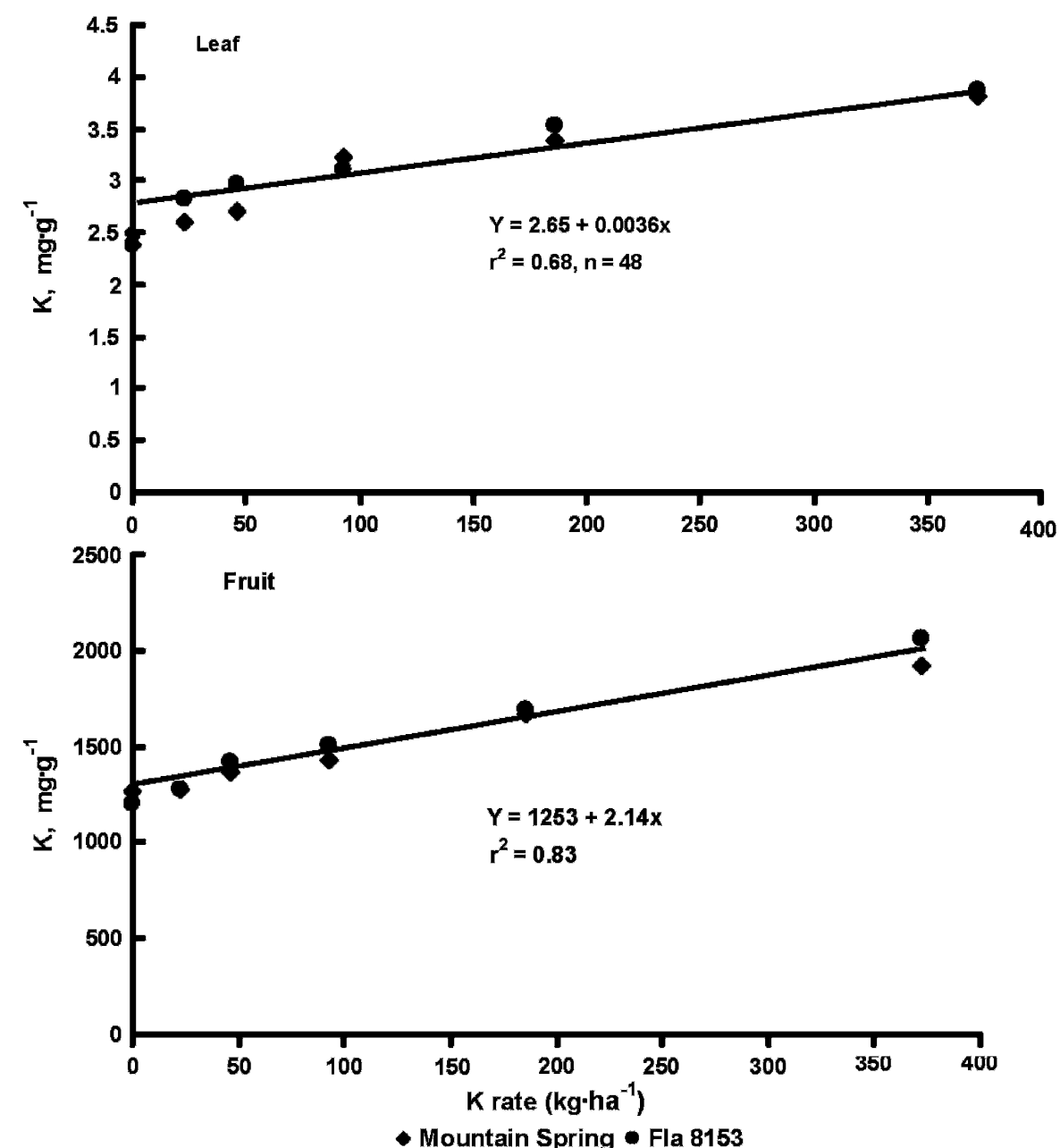

Fig. 2. Potassium fertilization effect on fresh market tomato whole-leaf K, dry weight basis, and fruit K, fresh weight basis, concentration. There was no significant difference between the two cultivars. Leaf sample taken 25 June 2004 when plants were rapidly flowering on the first and second truss. Fruit K concentration mean of four harvest dates and ranged from 1236 to $1991 \mathrm{mg} \cdot \mathrm{kg}^{-1}(\mathrm{n}=191, \mathrm{MSE}=163$ or $10.9 \%$ of the mean). 
was used for mean comparison. Other SAS routines used where appropriate included GLM, REG, and CORR (v 9.1e; SAS Institute, Cary, NC).

\section{Results and Discussion}

Field results. The 2004 growing season was nearly ideal for tomatoes, with cool temperatures and below normal rainfall, except for the month of May. May's monthly temperature averaged $1.8{ }^{\circ} \mathrm{C}$ degree above normal, with rainfall at $89 \mathrm{~mm}$ above normal. The remainder of the growing season until September was cool, at $6{ }^{\circ} \mathrm{C}$ degrees below normal, with below normal rainfall, at $-77 \mathrm{~mm}$. September warmed up with $5.4{ }^{\circ} \mathrm{C}$ degrees above normal and below normal rainfall of only $24 \mathrm{~mm}$. There were only 2 days during the season when the daily maximum high temperature exceeded $32{ }^{\circ} \mathrm{C}$. The first fall frost occurred 29 Sept.

There was no significant cultivar effect or interaction of cultivar and $\mathrm{K}$ rate on marketable fruit yield at any harvest date. The effect of $\mathrm{K}$ rate was evident at each harvest (data not presented), with higher $\mathrm{K}$ fertilization giving a larger total accumulative marketable yield (Fig. 1). The $\mathrm{K}$ rate effect on total marketable fruit yield was linear $(P<0.001)$. Both cultivars responded similarly. The effect was pronounced on the extra-large size category, with little response of the other size categories to $\mathrm{K}$ rate (data not presented). Extra-large fruit accounted for $82.5 \%$ of the total marketable fruit harvested, and large, medium, and small categories accounted for $14.1 \%, 2.7 \%$, and $0.9 \%$, respectively. Cullage represented $22.1 \mathrm{Mg} \cdot \mathrm{ha}^{-1}$ or $26 \%$ of total fruit harvested largely as the result of color disorders (blotchy ripened fruit) on the 31 Aug. and 7 Sept. harvest dates, a period of early morning high humidity. Cultivars did not differ in the amount of cull fruit nor did increasing the $\mathrm{K}$ application reduce the percentage of blotchy ripened fruit in this study. The low exchangeable $\mathrm{K}$ at our field site probably favored fruit ripening disorders, as found by Hartz et al. (1999) in California fields. In further experimentation with $\mathrm{K}$ fertilization of processing tomatoes, Hartz et al. (2005) showed that cultivar selection was the major factor associated with fruit color disorders, and a similar effect with fresh market tomatoes may also exist. In contrast to Fig. 1, 'Mountain Spring' was shown in a previous study to exhibit a linear-plateau response to applied $\mathrm{K}$ on our soil type, with optimal $\mathrm{K}$ application to be $246 \mathrm{~kg} \cdot \mathrm{ha}^{-1}$ producing $35.7 \mathrm{Mg} \cdot \mathrm{ha}^{-1}$ (Taber, 2006). The high yields we obtained in this study were favored by the ideal growing season weather of 2004 and we were not able to determine the $\mathrm{K}$ rate associated with maximum yield.

Leaf and fruit $K$ analysis. Whole-plant leaf $\mathrm{K}$ concentration at the onset of fruit enlargement (25 June) showed a linear response $(P<0.001)$ to applied K (Fig. 2). There was no difference between the cultivars in plant $\mathrm{K}$ accumulation. The leaf $\mathrm{K}$ concentrations, from $2.42 \mathrm{~g} \cdot \mathrm{kg}^{-1}$ at soil resid- ual $\mathrm{K}$ levels and rising to $3.85 \mathrm{~g} \cdot \mathrm{kg}^{-1}$ at the $372 \mathrm{~kg} \cdot \mathrm{ha}^{-1}$ rate, were similar to those reported in previous years (Taber, 2006).

Fruit $\mathrm{K}$ was measured on four harvest dates. Fruit $\mathrm{K}$ concentration response to applied $\mathrm{K}$ was similar to the leaf $\mathrm{K}$ response with a linear relationship $(P<0.01)$ recorded at every harvest date. Values rose from 1236 to $1991 \mathrm{mg} \cdot \mathrm{kg}^{-1}$, fresh weight basis (Fig. 2). Fruit $\mathrm{K}$ increases have been shown to follow increases in leaf $\mathrm{K}$ levels (Besford and Maw, 1975). A significant harvest date effect $(P<$ 0.01 ) occurred for 7 Sept., with fruit $\mathrm{K}$ concentration $226 \mathrm{mg} \cdot \mathrm{kg}^{-1}$ less than for the other three dates $\left(1564 \mathrm{mg} \cdot \mathrm{kg}^{-1}\right)$. There were no other main effects or interactions for fruit $\mathrm{K}$ concentration.

Interestingly, 'Fla. 8153' did not contain more fruit K than 'Mountain Spring' at any measured date. This was unexpected, as highlycopene 'Fla. 8153' is known to have higher lycopene than 'Mountain Spring' (Thompson et al., 2000) and thus should have accumulated more $\mathrm{K}$ as fruit $\mathrm{K}$ is correlated to carotenoid concentrations (Trudel and Ozbun, 1971). More recently, Fanasca et al. (2006) found no difference in fruit $\mathrm{K}$ concentration between a standard and a high-pigment cultivar even though fruit lycopene was $51 \%$ higher in the high-pigment cultivar compared with the standard cultivar.

Fruit lycopene analysis. Overall, 'Fla. 8153 ' fruit contained $53.7 \mathrm{mg} \cdot \mathrm{kg}^{-1}$ lycopene

Table 2. Analysis of variance (ANOVA) results of harvest dates, cultivar, and K rate treatments and their interactions on field fruit lycopene concentration.

\begin{tabular}{lrrrrr}
\hline Source $^{z}$ & DF & \multicolumn{1}{c}{ SS } & MS & F value & $P$ \\
\hline Block & 3 & 828.8 & 276.3 & 2.65 & 0.052 \\
Harvest (H) & 3 & 378.6 & 126.2 & 1.75 & 0.226 \\
Error (a) & 9 & 648.8 & 72.1 & & 0.283 \\
K rate (Kr) & 5 & 878.5 & 175.7 & 1.39 & $<0.0001$ \\
Error (b) & 15 & 1894.3 & 126.3 & 39.26 & 0.995 \\
Cultivar (Cv) & 1 & 4095.7 & 4095.7 & 0.29 & 0.902 \\
$\mathrm{H} * \mathrm{Kr}$ & 15 & 460.5 & 30.2 & 0.19 & 0.006 \\
$\mathrm{H} * \mathrm{Cv}$ & 3 & 59.8 & 19.9 & 3.46 & 0.999 \\
$\mathrm{Kr} * \mathrm{Cv}$ & 5 & 1805.1 & 361.0 & 0.20 & \\
$\mathrm{H} * \mathrm{Kr} * \mathrm{Cv}$ & 15 & 305.8 & 20.4 & & \\
Error (c) & 116 & 12102.0 & 104.3 & & \\
\hline ANOVA & & & & & \\
\hline
\end{tabular}

${ }^{\mathrm{z}}$ ANOVA using type 111 sum of squares of the SAS general linear procedure.

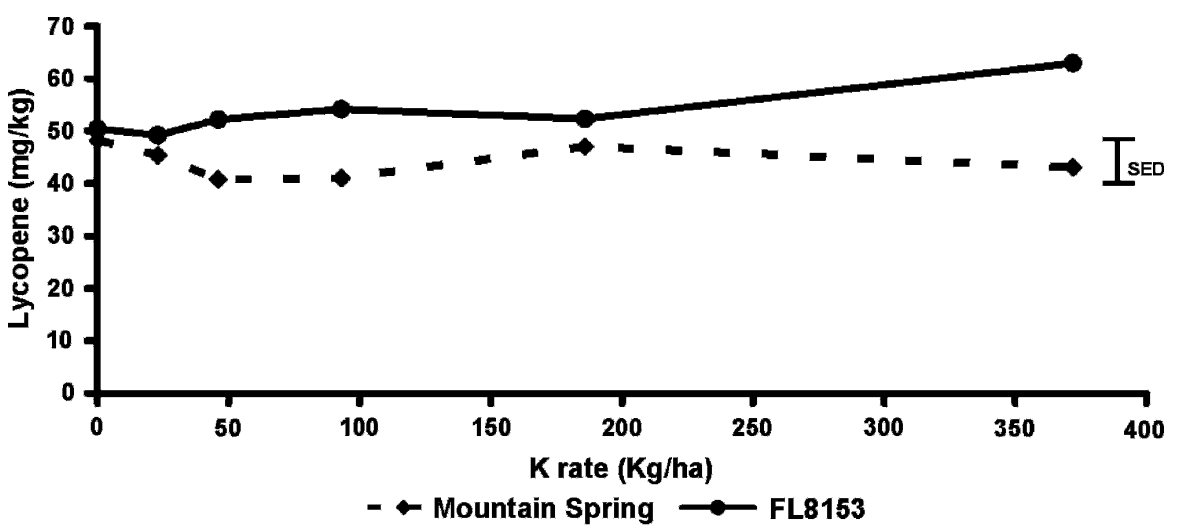

Fig. 3. Potassium fertilization effect on fruit lycopene concentration, fresh weight basis, for two tomato cultivars averaged across four harvest dates as measured by colorimetric techniques by USDA-ARS Laboratory, Lane, Oklahoma $(P=0.006, \mathrm{n}=191)$. The standard error of difference (SED) for comparison between cultivars at the same $\mathrm{K}$ rate $=3.57 \mathrm{mg} \cdot \mathrm{kg}^{-1}$. The SED bar for comparison between cultivars at different $\mathrm{K}$ rates $=3.78 \mathrm{mg} \cdot \mathrm{kg}^{-1}$. 
(Denisen, 1948; McCollum, 1956; Robertson et al., 1995).

Detailed carotenoid analysis (lycopene, phytoene, phytofluene, and $\beta$-carotene) was performed at the ISU laboratory by HPLC techniques on a subsample of fruit for the 24 Aug. harvest date where duplicate fruit slice samples were available. For fruit lycopene determination, the correlation of the ARS laboratory (colorimetric) and the ISU laboratory (HPLC techniques) for the 24 Aug. date samples was $\mathrm{r}=0.78$ (data not presented). However, with the limited dataset, the ISU laboratory found no correlation between fruit $\mathrm{K}$ concentration and fruit lycopene for either cultivar ('Fla. 8153', Fig. 5; 'Mountain Spring', data not shown). For 'Mountain Spring', the carotenoids phytoene and phytofluene were significantly correlated $(P=0.03)$ with fruit $\mathrm{K}$ concentration, but the

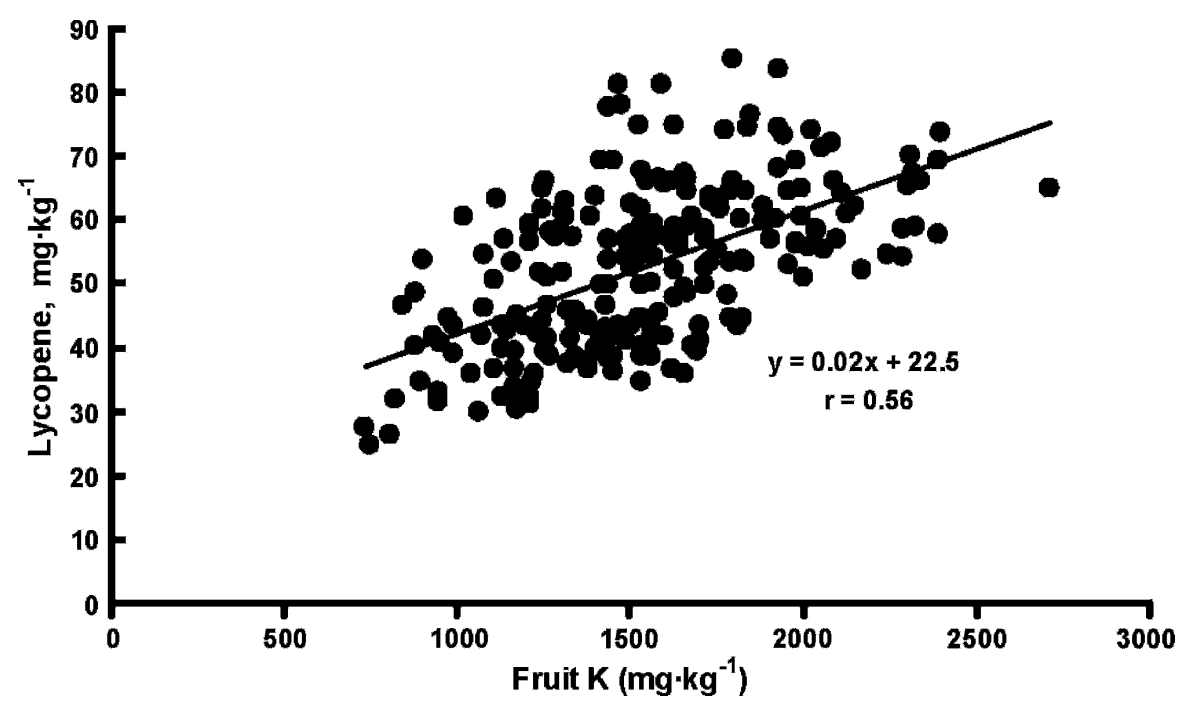

Fig. 4. Relationship of fruit $\mathrm{K}$ and lycopene concentration, fresh weight basis, for field-grown Fla. 8153, 2004. Individual fruit from four harvest dates, six K rates, and four replications $(\mathrm{n}=224)$.
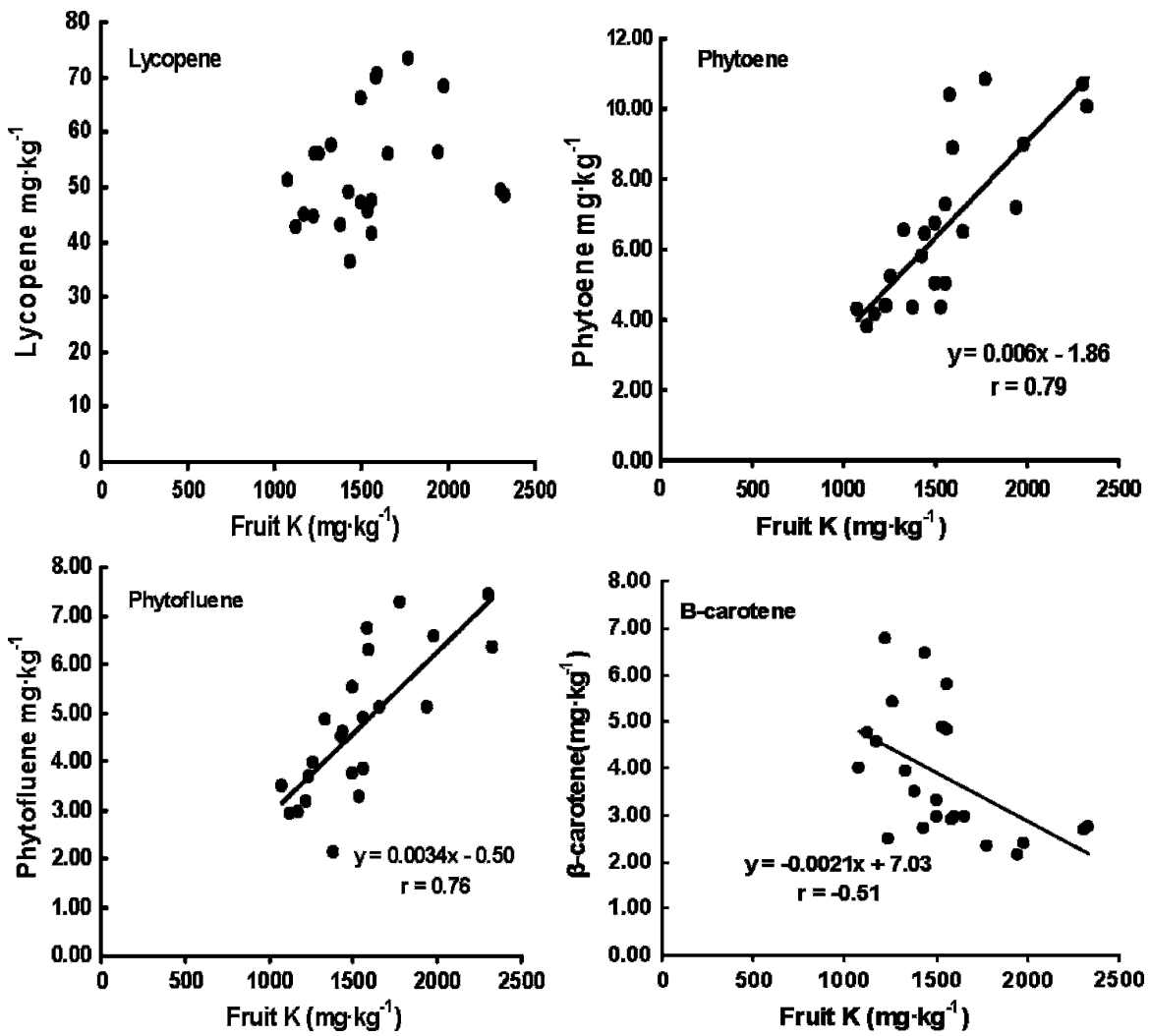

Fig. 5. Relationship of fruit K concentration to the fruit carotenoids for the Fla. 8153 from the 24 Aug. 2004 harvest date. Analysis by HPLC techniques, ISU laboratory $(\mathrm{n}=23)$. Fruit lycopene and fruit $\mathrm{K}$ were not correlated $(P=0.52)$. correlation was weak, $\mathrm{r}<0.46$. However, fruit $\mathrm{K}$ concentration of 'Fla. 8153' showed significant correlation $(P<0.0001)$ with phytoene and phytofluene, $r=0.79$ and 0.76, respectively (Fig. 5). Also, for this high-lycopene cultivar, increasing the fruit $\mathrm{K}$ significantly decreased $(P=0.01)$ the $\beta$-carotene concentration.

Greenhouse results. To further elucidate the effect of root zone $\mathrm{K}$ concentration on fruit lycopene production in commercial fresh market tomato cultivars, a controlled greenhouse study was established in Fall 2005. Similar to the field study, the K rate treatments doubled fruit $\mathrm{K}$ concentration, from 1326 to $2652 \mathrm{mg} \cdot \mathrm{kg}^{-1}$ (Table 3). There was no difference in fruit $\mathrm{K}$ concentration among the three cultivars, with an average fruit $\mathrm{K}$ concentration of $2070 \mathrm{mg} \cdot \mathrm{kg}^{-1}$. This value compares favorably with the 1991 $\mathrm{mg} \cdot \mathrm{kg}^{-1}$ for 'Mountain Spring' and 'Fla.

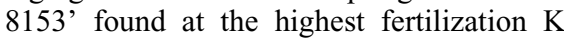
rate in the 2004 field study (Fig. 2). Fanasca et al. (2006) found no differences for fruit $\mathrm{K}$ concentration between standard and high-pigment tomato cultivars grown at a high $\mathrm{K}$ root zone treatment in a greenhouse environment.

Concentrations of lycopene, phytoene, phytofluene, and $\beta$-carotene were different depending on cultivar. 'Mountain Spring' and 'Florida 91' fruit concentrations of lycopene were similar, whereas the high-lycopene 'Fla. 8153 ' contained $38 \%$ more lycopene (70.5 vs. $51.7 \mathrm{mg} \cdot \mathrm{kg}^{-1}$, respectively; Table 3). For phytoene and phytofluene, 'Fla. 8153' contained significantly higher concentrations than the other two cultivars. In contrast, the high-lycopene 'Fla. 8153' contained 53.4\% less $\beta$-carotene.

Root zone $\mathrm{K}$ rate linearly $(P<0.001)$ increased fruit $\mathrm{K}$ concentration, a 2-fold response from 0 to $10 \mathrm{~mm} \cdot \mathrm{L}^{-1}$. Increasing root zone $\mathrm{K}$ also significantly $(P<0.01)$ enhanced fruit lycopene and the colorless precursors phytoene and phytofluene. Unlike the field study, there was no interaction of $\mathrm{K}$ rate and cultivar for lycopene concentration. Although less dramatic than the effect on fruit $\mathrm{K}$, lycopene increased 1.2-fold with high root zone K. Media K rate effect on phytoene and phytofluene was quadratic, with concentrations peaking at 13.6 and $8.1 \mathrm{mg} \cdot \mathrm{kg}^{-1}$, respectively, at $7 \mathrm{mM} \cdot \mathrm{L}^{-1} \mathrm{~K}$.

There was a positive correlation between fruit $\mathrm{K}$ and lycopene content for high-lycopene 'Fla. 8153 ', $\mathrm{r}=0.53(P=0.04)$, but not for the other two standard cultivars (Table 4). These results were similar to our 2004 field study, with the exception of the limited 24 Aug. data with HPLC analysis. In all three cultivars, a stronger correlation was found between fruit $\mathrm{K}$ and phytoene and phytofluene than with lycopene (Table 4).

Potassium may be involved in one or more enzymes, such as phytoene synthase or phytoene desaturase, that synthesize phytoene from geranylgeranyldiphosphate, which is the first committed step in the carotenoid biosynthetic pathway (RodriquezAmaya, 2001; Fig. 6). The Rodermel 
Table 3. Tomato fruit concentrations of $\mathrm{K}$ and carotenoids as affected by cultivar and $\mathrm{K}$ nutrient solution level in the greenhouse, Fall 2005. Fruit were harvested from 29 Nov. to $22 \mathrm{Dec}$. at $7 \mathrm{~d}$ after breakerstage of development $(\mathrm{n}=111)$.

\begin{tabular}{|c|c|c|c|c|c|}
\hline \multirow[b]{2}{*}{ Cultivar } & $\mathrm{K}$ & Lycopene & Phytoene & Phytofluene & $\beta$-carotene \\
\hline & \multicolumn{5}{|c|}{ Fruit concentration, $\mathrm{mg} \cdot \mathrm{kg}^{-1}$, fresh weight basis } \\
\hline Mountain Spring & 2056 & 50.5 & 9.8 & 5.8 & 5.6 \\
\hline Florida 91 & 2067 & 51.7 & 11.2 & 6.7 & 6.0 \\
\hline Fla. 8153 & 2088 & 70.5 & 14.4 & 8.8 & 2.7 \\
\hline $\mathrm{SED}^{\mathrm{z}}$ & NS & 2.78 & 0.78 & 0.38 & 0.34 \\
\hline \multicolumn{6}{|l|}{$\mathrm{K}$ rate, $\mathrm{mm} \cdot \mathrm{L}^{-1}$} \\
\hline 0 & 1326 & 51.3 & 9.5 & 5.9 & 5.0 \\
\hline 2.5 & 1967 & 55.9 & 11.5 & 7.0 & 4.8 \\
\hline 5.0 & 2339 & 60.0 & 13.5 & 8.0 & 4.7 \\
\hline 10.0 & 2652 & 63.0 & 12.8 & 7.6 & 4.6 \\
\hline Significance $^{\mathrm{y}}$ & $\mathrm{L} * *$ & $\mathrm{~L} * *$ & $\mathrm{Q} * *$ & $\mathrm{Q} * *$ & NS \\
\hline
\end{tabular}

${ }^{\mathrm{z}_{\mathrm{SED}}}=$ standard error of difference for comparison among the cultivars.

${ }^{\mathrm{y}}$ Regression analysis in which $\mathrm{ns}=$ nonsignificant; $\mathrm{L}=$ linear; $\mathrm{Q}=$ quadratic; significance at $* * P<0.01$.

Table 4. Correlation coefficient of tomato fruit $\mathrm{K}$ concentration with the fruit carotenoids in a greenhouse study, Fall 2005.

\begin{tabular}{|c|c|c|}
\hline Carotenoid & $\begin{array}{l}\text { Fruit K of } \\
\text { Fla. } 8153\end{array}$ & $\begin{array}{c}\text { Fruit K of } \\
\text { Mountain } \\
\text { Spring + Florida 91 }\end{array}$ \\
\hline Lycopene & $0.53 * z$ & 0.25 \\
\hline Phytoene & $0.63 * *$ & $0.40 *$ \\
\hline Phytofluene & $0.65 * *$ & $0.36 *$ \\
\hline B-carotene & $-0.64 * *$ & -0.07 \\
\hline
\end{tabular}

z*,**Significant at $P<0.05$ or 0.01 , respectively.
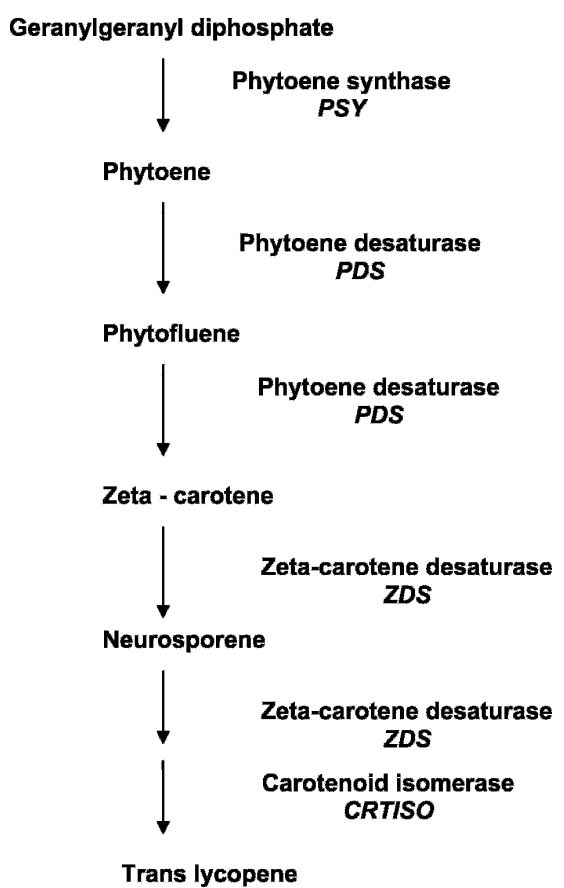

Fig. 6. Lycopene biosynthesis pathway. Adapted from Rodriguez-Amaya (2001).

laboratory cloned and purified the product of the tomato ghost gene (gh), which was shown to be the plastid terminal oxidase (Bae et al., 1999). The ghost mutant is characterized by a defect in lycopene biosynthesis. These studies directly implicate electron transport in the desaturation of phytoene to form lycopene. Potassium has a known role in ATP synthesis, proton uptake, and electron flow in the thylakoid membranes of plastids, which are the site of carotenoid biosynthesis (Lebedeva et al., 2002; Quitrakul and Izawa, 1973). Thus, the effect of K on lycopene biosynthesis may be indirectly mediated by the electron transport chain involved in phytoene desaturation.

A significant $(P<0.01)$ negative relationship, $\mathrm{r}=-0.64$, was found for fruit $\mathrm{K}$ and $\beta$-carotene only for 'Fla. 8153' (Table 4). This same phenomenon occurred in the field study (Fig. 5), but did not occur with a highpigment cultivar used in greenhouse studies by Fanasca et al. (2006). Lycopene is converted to $\beta$-carotene through the enzyme lycopene b-cyclase. In crimson gene tomatoes, $\beta$-carotene synthesis is reduced (Thompson et al., 1967), possibly through inactivation of this enzyme.

\section{Conclusion}

In this study, a positive effect of $\mathrm{K}$ fertility on tomato carotenoids was found in greenhouse and field experiments, with the degree of response dependent of genotype. In common with other studies, fruit lycopene concentration of cultivars with average lycopene concentration does not appear to be affected by $\mathrm{K}$ application in excess of recommended rates. However, high-lycopene tomato types may respond positively to additional soilapplied K.

\section{Literature Cited}

Anac, D. and H. Colakoglu. 1995. Response of some major crops to $\mathrm{K}$ fertilization, p. 235 247. In: K. Mengel, A. Krauss (eds.) K availability of soils in West Asia and North Africa: Status and Perspectives. International Potash Institute, Basel, Switzerland.

Ansari, M.S. and N.P. Gupta. 2003. A comparison of lycopene and orchidectomy vs orchidectomy alone in the management of advanced prostate cancer. BJU Int. 92:375-378.

Bae H., Sr., F. Rodermel, and C. Wetzel. 1999. Tomato GHOST and Arabidopsis IMMUTANS are homologous variegation loci that function in phytoene desaturation and chloroplast development. Plant Biol. 140:14-26.

Barr, J., W.S. White, L. Chen, H. Bae, and S.R. Rodermel. 2003. The GHOST terminal oxidase is required for carotenoid biosynthesis, plastid biogenesis, and tissue morphogenesis dur- ing tomato fruit ripening. Plant Cell Environ. 27:1-13.

Bartley, G.E., P.A. Scolnik, and P. Beyer. 1999. Two Arabidopsis thaliana carotene desaturases, phytoene desaturase and $\beta$-carotene desaturase, expressed in Escherichia coli, catalyze a poly-cis pathway to yield pro-lycopene. Eur. J. Biochem. 259:396-403.

Besford, R.T. and G.A. Maw. 1975. Effect of potassium nutrition on tomato plant growth and fruit development. Plant Soil 42:395-412.

Brown, J.R. 1998. Recommended chemical soil test procedures for the North Central Region. NCR Research Publication No. 221, University of Missouri, Columbia.

Davis, A.R., W.W. Fish, and P. Perkins-Veazie. 2003. A rapid spectrophotometric method for analyzing lycopene content in tomato and tomato products. Postharvest Biol. Technol. 28:425-430.

Denisen, E.L. 1948. Tomato color as influenced by variety and environment. Proc. Amer. Soc. Hort. Sci. 51:349-56.

Fanasca, S., G. Colla, G. Maiani, E. Venneria, Y. Rouphael, E. Assini, and F. Saccardo. 2006. Changes in antioxidant content of tomato fruits in response to cultivar and nutrient solution composition. J. Agr. Food Chem. 54:43194325.

Fish, W., P. Perkins-Veazie, and J.K. Collins. 2002. A quantitative assay for lycopene that utilizes reduced volumes of organic solvents. J. Food Comp. Anal. 15:309-317.

Fraser, P.D., M.R. Truesdale, C.R. Bird, W. Schurch, and P. Bramley. 1994. Carotenoid biosynthesis during tomato fruit development. Plant Physiol. 105:405-413.

Giovannucci, E. 2002. A review of epidemiologic studies of tomatoes, lycopene, and prostate cancer. Exp. Biol. Med. 227:852-859.

Hartz, T.K., G. Miyao, R.J. Mullen, M.D. Cahn, J. Valencia, and K.L. Brittan. 1999. Potassium requirements for maximum yield and fruit quality of processing tomato. J. Amer. Soc. Hort. Sci. 124:199-204.

Hartz, T.K., P.R. Johnstone, D.M. Francis, and E.M. Miyao. 2005. Processing tomato yield and fruit quality improved with potassium fertigation. HortScience 40:1862-1867.

Hoagland, D.R. and D.I. Arnon. 1950. The water culture method for growing plants without soil. Circular 347. Berkeley, CA, California Agricultural Experimental Station.

Konsler, T.K. and R.G. Gardner. 1990. Commercial production of staked tomatoes in North Carolina. N.C. State University Agr. Ext. Serv. Publ. AG-405.

Lebedeva, G.V., N.E. Belyaeva, O.V. Demin, G.Y. Riznichenko, and A.B. Rubin. 2002. A kinetic model of primary photosynthetic processes. Description of the fast phase of chlorophyll fluorescence induction at different light intensities. Biofizika 47:1044-1058.

Lester, G.E. and K.M. Crosby. 2002. Ascorbic acid, folic acid, and potassium content in postharvest green-flesh honeydew muskmelons: Influence of cultivar, fruit size, soil type, and year. J. Amer. Soc. Hort. Sci. 127:843-847.

McCollum, J.P. 1956. Sampling tomato fruits for composition studies. Proc. Amer. Soc. Hort. Sci. 68:587-595.

Minorsky, P.V. 2002. Lycopene and the prevention of prostate cancer: The love apple lives up to its name. Plant Physiol. 130:1077-1078.

Ong, A.S.H. and E.S. Tee. 1992. Natural sources of carotenoids from plants and oils. Methods Enzymol. 213:142-167. 
Palozza, P. and N.I. Krinsky. 1992. Antioxidant effects of carotenoids in vivo and in vitro: An overview. Methods Enzymol. 213:403-420.

Perkins-Veazie, P. and W. Roberts. 2003. Can potassium application affect the mineral and antioxidant content of horticultural crops? Amer. Soc. Agron. Proc. Symposium in Fertilizing Crops for Functional Food, pp. 2/1-2/6.

Quitrakul, R. and S. Izawa. 1973. Electron transport and photophosphorylation in chloroplasts as a function of the electron acceptor. Biochim. Biophys. Acta 305:105-118.

Rissanen, T.H., S. Voutilainen, K. Nyyssönen, R. Salonen, G.A. Kaplan, and J.T. Salonen. 2003. Serum lycopene concentrations and carotid atherosclerosis: The Kuopio Ischaemic Heart Disease Risk Factor Study. Amer. J. Clin. Nutr. 77:133-138.

Robertson, G.H., N.E. Mahoney, N. Goodman, and A.E. Pavlath. 1995. Regulation of lycopene formation in cell suspension culture of VFNT tomato (Lycopersicon esculentum) by CPTA, growth regulators, sucrose, and temperature. J. Expt. Bot. 46:667-673.
Rodriquez-Amaya, D.B. 2001. A guide to carotenoid analysis in foods. ILSI Press, International, Life Sciences Institute, Washington, DC

Sacks, E.J. and D.M. Francis. 2001. Genetic and environmental variation for tomato flesh color in a population of modern breeding lines. J. Amer. Soc. Hort. Sci. 126:221-226.

Soltanpour, P.N., G.W. Johnson, S.M. Workman, J.B. Jones, Jr., and R.O. Miller. 1996. Inductively coupled plasma emission spectrometry and inductively coupled plasma-mass spectroscopy, p. 91-140. In: J.M. Bartels (ed.). Methods of soil analysis. Part 3. Chemical methods. Soil Science Society of America, American Society of Agron., Madison, WI.

Stommel, J.R. 2007. Genetic enhancement of tomato fruit nutritive value, p. 193-238. In: M.K. Razdan and A.K. Matoo (eds.). Genetic improvement of solanaceous crops. Vol. 2: Tomato. Science Publishers, Enfield, NH.

Taber, H.G. 2006. Potassium application and leaf sufficiency level for fresh-market tomatoes grown on a Midwestern United States finetextured soil. HortTechnology 16:247-252.
Thompson, A.E., M.L. Tomes, H.T. Erickson, E.V. Wann, and R.J. Armstrong. 1967. Inheritance of crimson fruit color in tomato. Proc. Amer. Soc. Hort. Sci. 91:495-504.

Thompson, K.A., M.R. Marshall, C.A. Sims, C.I. Wei, S.A. Sargent, and J.W. Scott. 2000. Cultivar, maturity, and heat treatment on lycopene content in tomatoes. J. Food Sci. 65:791-795.

Trudel, M.J. and J.L. Ozbun. 1971. Influence of potassium on carotenoid content of tomato fruit. J. Amer. Soc. Hort. Sci. 96:763-765.

Widders, J.E. and O.A. Lorenz. 1979. Tomato root development as related to potassium nutrition. J. Amer. Soc. Hort. Sci. 104:216-220.

Wilcox, G.E. 1964. Effect of potassium on tomato growth and production. J. Amer. Soc. Hort. Sci. 85:484-489.

Wyn Jones, R.G. and A. Pollard. 1983. Proteins, enzymes and inorganic ions. p. 528-562. In: A. Lauchli and R.L. Bieleski (eds.). Inorganic plant nutrition. Springer-Verlag, Berlin.

Zechmeister, L. and A. Polgar. 1943. Cis-trans isomerization and spectral characteristics of carotenoids and some related compounds. J. Am. Chem. Soc. 65:1522-1528. 